\title{
Biliopancreatic tumors: patient survival and quality of life after palliative treatment
}

\author{
M. V. García Sánchez, P. López Vallejos, D. Pérez de Luque, A. Naranjo Rodríguez, A. Hervás Molina, \\ A. González Galilea, B. Calero Ayala, J. Padillo Ruiz, G. Solórzano Peck and J. F. de Dios Vega \\ Service of Digestive Diseases. Hospital Universitario Reina Sofía. Córdoba, Spain
}

\begin{abstract}
Objectives: to analyse survival and quality of life of patients with malignant obstructive jaundice after palliative treatment, comparing endoscopic stent insertion and palliative surgical (pallative resection and bypass surgical).

Patients and method: eighty and seven patients were included in a trial. They were distributed to endoscopic stent (50) and palliative surgical (37). It analysed survival, quality of life and comfort index of jaundiced patients. The good quality of life was defined by absence of jaundice, pruritus and cholangitis after the initial treatment.

Results: the median survival of the patients treated to endoscopic stent was 9,6 months whereas the patients to surgical treatment survived a median of 17 months. The time free of disease was 4 months in stented patients and 10,5 months in surgical patients. There was no significant difference in comfort index between the two groups (stented 34\%, surgical 42,5\%). Neither was there significant difference in survival and quality of life between palliative resection and bypass surgery.

Conclusions: despite the survival and time free of disease being better in surgical patients, there was no significant difference in overall quality of life between the two groups. The survival and quality of life are the same after palliative resection as after bypass surgery, for this should not be performed routinely or to justify resection as a debulking procedure.
\end{abstract}

Key words: Malignant bile duct obstruction. Quality of life. Endoprostheses. Bypass surgical. Palliative treatment.

García Sánchez MV, López Vallejos $P$, Pérez de Luque D, Naranjo Rodríguez A, Hervás Molina A, González Galilea A, Calero Ayala B, Padillo Ruiz J, Solórzano Peck G, de Dios Vega JF. Biliopancreatic tumors: patient survival and quality of life after palliative treatment. Rev Esp Enferm Dig 2004; 96: 305314.

Recibido: 02-09-03

Aceptado: 19-11-03.

Correspondencia: María del Valle García Sánchez. Secretaria de Aparato Digestivo. Hospital Universitario Reina Sofía. Avda. Menéndez Pidal, s/n. 14004 Córdoba. Tel.: 9570102 05. e-mail: vallegarcia@ supercable.es

\section{INTRODUCTION}

The main causes of malignant obstruction of the main biliary duct are ampullary carcinoma, adenocarcinoma of the pancreatic head, cholangiocarcinoma and vesicular cancer (1).

Although surgery is still the only treatment to cure these neoplasias, on most occasions it is not possible. On the one hand, the generally advanced age of these patients usually leads to the association with serious diseases, making surgery unadvisable or significantly increasing postoperative morbidity and mortality $(2,3)$. On the other hand, the evolutionary stage of these tumors at the time of diagnosis makes them non-resectable in many cases (2-4). These two facts explain why over $75 \%$ of these patients only receive palliative treatment $(2,4,5)$.

The palliative alternatives currently available for alleviating biliary duct obstruction are endoscopic or percutaneous biliary drainage by stenting and biliodigestive bypass surgery with non-curative resection. Up to the mid-1980s, these patients underwent surgery to attempt resection or, in most cases, palliative biliary drainage (6). From the 1980s onwards, percutaneous drainage began to be used, though the morbidity linked to the technique led to its being relegated in favor of endoscopic drainage (7). Despite multiple trials suggesting endoscopic stenting is a safe and effective technique with a low rate of perioperative complications and mortality, its superiority over bypass surgery has yet to be demonstrated $(8,13)$. On the other hand, the purpose of these treatments is not only to palliate jaundice and increase patient survival, but also to increase the disease-free survival between diagnosis and patient death. In this sense, studies exist demonstrating an improvement in quality of life in patients with malignant obstruction of the biliary duct following endoscopic stenting $(14,15)$, but very few have contrasted results between this therapy and palliative surgery. The main objective of our study, therefore, is to analyze survival and 
quality of life resulting from endoscopic stenting and palliative surgery in patients with malignant obstructive jaundice of the main biliary duct.

\section{PATIENTS AND METHOD}

A retrospective study was carried out of 87 patients with malignant obstruction of the biliary duct receiving palliative treatment who were admitted to hospital between January 1998 and December 2001. Only patients with a malignant histological diagnosis or cholangiography and at least one other compatible image technique (ultrasound, CAT or cholangio-MRI), and who followed a clinical evolution of malignant disease, were included. Patients with a prior history of another neoplastic disease during the 5 previous years were excluded, as were those with difficult endoscopic access to the papilla (e.i. Billroth II gastrectomy) and those who received percutaneous stenting by means of transhepatic cholangiography.

Patients were divided into two groups according to palliative treatment applied. Group 1 included 50 patients who received endoscopic stenting. Group 2 contained 37 patients who underwent surgical treatment.

The procedure was considered satisfactory when, besides correct stent insertion or surgical biliodigestive anastomosis, the patient's clinical evolution was favorable (pruritus improvement and a drop in serum bilirubin levels of at least $30 \%$, five days after drainage) and ultrasound controls showed a decrease in duct caliber. Drainage was considered ineffective if these criteria were not met.

All patients were monitored until their death, with a revision 30 days after drainage and then quarterly, including analysis and abdominal ultrasound on each visit.

The following clinical and analytical variables were gathered: age, sex, presence of associated medical diseases, tumor type, leukocyte count, hemoglobin, serum creatinine, bilirubin and alkaline phosphatase levels.

Complications and mortality in the first 30 days after treatment were defined as early morbidity and mortality, respectively. The hospital stay was registered after surgery or initial stent insertion, the number and causes of readmissions, and the need for new surgery on the biliary or digestive ducts. Patient survival and quality of life were analyzed, with good quality of life defined as absence of jaundice, pruritus and cholangitis after initial treatment. The comfort index was calculated so that the period of good quality of life is expressed as a survival percentage (16).

Comfort index: $\frac{\text { Good quality of life (months) }}{\text { Survival (months) }} \times 100$

Endoscopic biliary drainage was performed under sedation with midazolam i.v., using Olympus TJF-10 and TJF-130 duodenoscopes with a $4.2 \mathrm{~mm}$ channel. Following dilatation, Amsterdam (Izasa-GIP Medizintech-nik) or Pig-Tail (Baston Scientific/Microvasive) polyethylene stents were inserted using, in almost all cases, a $10 \mathrm{~F}$ caliber which varied in length depending on the state of the stenosis. Palliative surgery was decided upon by the team of surgeons responsible for the patient. A palliative resection was performed in 20 patients, while 17 underwent biliodigestive bypass surgery by means of choledochoduodenostomy, cholecystostomy or gastroenterostomy. No patient received complementary radiochemotherapy.

A descriptive study was made of the variables gathered for each group, and a Kaplan-Meier curve was used to analyze survival and disease-free survival.

\section{RESULTS}

Mean age was 70.6 years (range 37-92), 42 were male, and 51 had serious associated chronic diseases. Table I shows the general characteristics of each group.

Table I. General characteristics

\begin{tabular}{|c|c|c|}
\hline & Group 1 & Group 2 \\
\hline Number (n) & 50 & 37 \\
\hline Age $($ mean $\pm S D)$ & $70 \pm 10$ & $64 \pm 11$ \\
\hline \multicolumn{3}{|l|}{ Sex: $n(\%)$} \\
\hline Male & $23(46)$ & $19(51)$ \\
\hline Female & $27(54)$ & $18(49)$ \\
\hline Associated diseases, n (\%) & $30(60)$ & $21(57)$ \\
\hline \multicolumn{3}{|l|}{ Type of tumor: $n(\%)$} \\
\hline Proximal & $15(30)$ & $8(22)$ \\
\hline Distal & $19(38)$ & $22(59)$ \\
\hline Ampulloma & $16(32)$ & $7(19)$ \\
\hline $\begin{array}{l}\text { Leukocytes, } \mathrm{mm}^{3} / \mathrm{dl} \\
\quad(\text { mean } \pm \mathrm{SD})\end{array}$ & $8009 \pm 3251$ & $7543 \pm 2250$ \\
\hline $\begin{array}{l}\text { Hemoglobin, g/dl } \\
(\text { mean } \pm \text { SD })\end{array}$ & $12 \pm 1,4$ & $13 \pm 1,35$ \\
\hline $\begin{array}{l}\text { Creatinine, g/dl } \\
\quad(\text { mean } \pm \text { SD })\end{array}$ & $1,1 \pm 1,1$ & $1 \pm 0,2$ \\
\hline $\begin{array}{l}\text { Total bilirubine, mg/dl } \\
\quad(\text { mean } \pm \text { SD) } \\
\text { Alkaline phosphatase, UI/L }\end{array}$ & $16 \pm 8$ & $12 \pm 9$ \\
\hline$($ mean $\pm S D)$ & $1038 \pm 1073$ & $972 \pm 629$ \\
\hline
\end{tabular}

The level of obstruction was located in the proximal biliary duct in 23 patients $(26 \%)$, in the distal biliary duct in 41 subjects (48\%), and in $23(26 \%)$ cases it was due to an ampullary tumor. Table II shows series distribution by neoplasm location.

Tables III and IV show the results of the prognostic variables according to type of palliative treatment applied (endoscopic, surgical), and surgical technique used (palliative resection, bypass surgery). 
Table II. Neoplasm location

\begin{tabular}{lcc}
\hline Type of tumor & $n$ & Percentage \\
\hline Ampulloma & 23 & 26 \\
Pancreatic cancer & 35 & 40 \\
Vesicular cancer & 11 & 13 \\
Cholangiocarcinoma & 18 & 21 \\
Bismuth type I & 3 & 17 \\
Bismuth type II-III & 4 & 22 \\
Medium / Distal & 11 & 61 \\
\hline
\end{tabular}

n: sample size. p: probability

Table III. Prognostic variables

\begin{tabular}{lcc}
\hline & Group 1 & Group 2 \\
\hline Effectiveness of the technique: $\mathrm{n}(\%)$ & $47(94)$ & $35(95)$ \\
Early morbidity: $\mathrm{n}(\%)$ & $4(8)$ & $12(32)$ \\
Early mortality: $\mathrm{n}(\%)$ & $6(12)$ & $4(11)$ \\
Hospital stay, days: & & \\
$\quad$ mean \pm SD & $12,5 \pm 7,5$ & $35 \pm 10$ \\
Readmissions: $\mathrm{n}(\%)$ & $14(28)$ & $5(8)$ \\
Reoperations: $\mathrm{n}(\%)$ & $11(22)$ & $5(13)$ \\
$\quad$ ERCP & 9 & 0 \\
$\quad$ Surgery & 2 & 5 \\
$\begin{array}{l}\text { Time free of disease, months: } \\
\quad \text { mean } \pm \text { SD }\end{array}$ & $4 \pm 5,5$ & $10,5 \pm 14$ \\
$\quad \begin{array}{l}\text { Survival, months: } \\
\quad \text { mean } \pm \text { SD }\end{array}$ & $9,6 \pm 10,6$ & $17 \pm 19$ \\
$\quad$ Comfort index, \%: & $34 \pm 23$ & $42,5 \pm 29$ \\
$\quad$ mean \pm SD & &
\end{tabular}

Table IV. Prognostic measures according to surgical treatment applied

\begin{tabular}{lcc}
\hline & Resection & Bypass \\
\hline Number $(n)$ & 20 & 17 \\
Early morbidity: $n(\%)$ & $6(30)$ & $6(35)$ \\
Early mortality: $n(\%)$ & $1(5)$ & $3(17)$ \\
Hospital stay, days: mean \pm SD & $35,7 \pm 10,6$ & $34 \pm 9,3$ \\
Readmissions: $n(\%)$ & $2(10)$ & $1(6)$ \\
Reoperations: $n$ (\%) & $4(20)$ & $1(6)$ \\
Time free of disease, months: & & \\
$\quad$ mean \pm SD & $11 \pm 11$ & $10 \pm 17$ \\
Survival, months: mean \pm SD & $18 \pm 16$ & $16 \pm 22,6$ \\
Comfort index, \%: mean \pm SD & $54 \pm 26$ & $29 \pm 27$ \\
\hline
\end{tabular}

n: sample size; p: probability; SD: standard desviation.

Table V shows disease-free survival, survival and comfort index by tumor location and type of palliative treatment used. We found that the result for these variables was better after surgery, though not significantly. Ampulloma was the tumor with the best prognosis, and vesicular carcinoma received the worst prognosis.

Endoscopic drainage was achieved satisfactorily in 47 patients (94\%), and biliodigestive anastomosis in 35 (95\%). Early morbidity occurred in 16 patients, $32 \%$ in the surgery group and $8 \%$ in the endoscopy group. The most frequent complications were those resulting from a dehiscence of the
Table V. Survival and quality of life according to tumor location and palliative treatment applied

\begin{tabular}{cccc}
\hline & TFD $(m)$ & $S(m)$ & $C l(\%)$ \\
\hline Pancreatic adenocarcinoma & & & \\
$\quad$ Group 1: 14 & $3 \pm 6$ & $7 \pm 10$ & $32 \pm 25$ \\
$\quad$ Group 2: 21 & $9 \pm 9$ & $15 \pm 15$ & $42 \pm 28$ \\
Ampullary carcinoma & & & \\
$\quad$ Group 1: 16 & $6 \pm 5$ & $16 \pm 12$ & $37 \pm 23$ \\
$\quad$ Group 2: 7 & $22 \pm 22$ & $35 \pm 27$ & $45 \pm 35$ \\
Cholangiocarcinoma & $2 \pm 2$ & $6 \pm 6$ & $30 \pm 15$ \\
$\quad$ Group 1: 16 & $18 \pm 25$ & $19 \pm 24$ & $75 \pm 35$ \\
$\quad$ Group 2: 2 & & & \\
Vesicular neoplasm & $6 \pm 12$ & $7 \pm 11$ & $41 \pm 44$ \\
$\quad$ Group 1: 4 & $2 \pm 2$ & $5 \pm 5$ & $33 \pm 24$ \\
$\quad$ Group 2: 7 &
\end{tabular}

TFD (m): time free of disease (months). S (m): survival (months). $\mathrm{Cl}$ (\%): comfor index (\%).

anastomosis (6), followed by respiratory complications (3), renal insufficiency (3), infections (2), cardiac decompensation (1) and upper gastrointestinal bleeding (1). Early mortality was similar in both groups, in 6 cases due to the advanced state of the neoplastic disease, and in another 4 following complications in the biliary drainage ( 2 after endoscopic drainage and 2 after surgical drainage).

Although the number of readmissions was higher in the endoscopically drained group than the surgical group (14/50 and 5/37, respectively), no significant difference was found in the need for repeat endoscopies or surgery (11/50 and 5/37). Eleven patients from the endoscopy group required subsequent repeat treatment, 10 due to obstruction of the stent, which was replaced (it was replaced once in 5 patients, twice in 4, and four times in 1), and one for bypass surgery due to duodenal obstruction secondary to tumor growth. Surgical reintervention was required in the 5 patients in group 2 due to suture dehiscence at the anastomosis. Mean hospital stay after the initial procedure was greater in the surgery group than in the endoscopy group.

Higher rates of survival and disease-free survival were higher in the patients who received surgery than in those who underwent endoscopic drainage (Figs. 1 and 2), though no significant differences were found in the comfort index between the two procedures.

Survival, disease-free survival and comfort index ratio were greater in the group who received resection surgery than in the patients undergoing bypass surgery (Table IV), with no significant differences in the rest of the prognostic variables.

\section{DISCUSSION}

Endoscopic biliary drainage and palliative surgery are accepted options in malignant obstructive jaundice, with a success rate of over $90 \%$ and no significant differences 


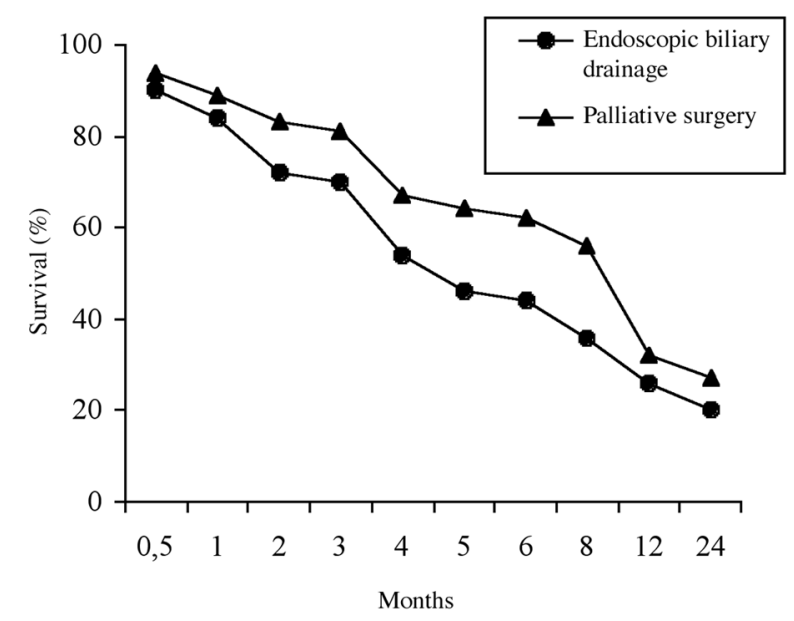

Fig. 1.- Actuarial curve of patient survival specifying the type of palliative treatment applied.

Curva actuarial de supervivencia de los pacientes especificando el tipo de tratamiento paliativo aplicado.

between the two $(17,18)$. Effectiveness in our series was 94\% in the group who underwent endoscopic biliary drainage, and $95 \%$ in the group receiving surgery.

Early mortality in our patients was similar to that in other series published to date, which is around 8-24\% (17-21). However, previous studies have suggested that the development of perioperative complications is more frequent in the surgery group than in the endoscopy group (17-19). The randomized trial by Smith et al (17), which considers and defines early morbidity in a very similar way to that of our study, obtained $29 \%$ of complications with surgery, compared with $11 \%$ after endoscopic stent insertion. In our series, morbidity was $32 \%$ after surgery and 8 after endoscopic stenting.

Three studies $(18,20,21)$, one of which was randomized (18), have also shown that endoscopic palliative treatment lowers the number of days in hospital when compared to surgery. In our series, patients who received endoscopic biliary drainage stayed in hospital for 12.5 days, compared with 35 days for patients undergoing palliative surgery.

One of the main inconveniences of endoscopic treatment versus surgery is a higher percentage of readmissions after the initial operation. These results have been published in various clinical trials, though statistical significance tests have not been reported $(18,20,21)$. In our series, $28 \%$ of the endoscopically drained patients were readmitted to hospital, compared to $8 \%$ from the surgery group. The development of jaundice, in some cases with cholangitis and even sepsis, was the most frequent cause of readmission, and the need for stent replacement the main reason for reintervention on the biliary duct. It has been stated that $37 \%$ of plastic stents occlude despite preventive measures (biliary salts), as a consequence of the deposit of amorphous material on the inner surface, and

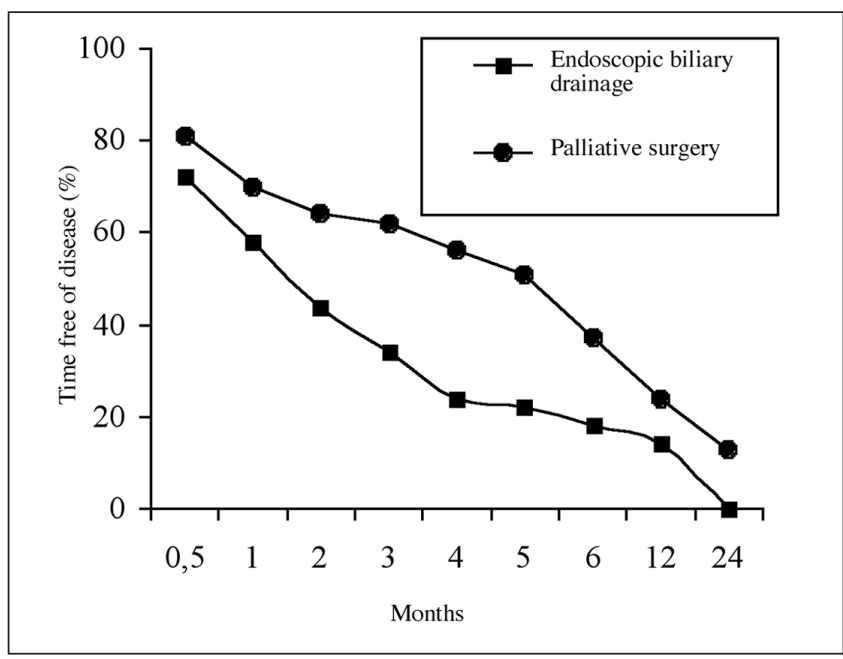

Fig. 2.- Actuarial curve of disease-free survival for patients, specifying the type of palliative treatment applied.

Curva actuarial de tiempo asintomático de los pacientes especificando el tipo de tratamiento paliativo aplicado.

in these cases the stent must be replaced $(17,22)$. In our series, the percentage was somewhat higher at $41 \%$, and the mean number of stents per patient was 1.7, a similar figure to that published by Raiker et al (20).

In the analysis of survival in patients with malignant obstructive jaundice, in terms of the palliative treatment applied, no significant differences are found in the studies published to date $(17,19-21)$. However, in our series, patient survival was $17 \pm 19$ months in the surgery group, and $9.6 \pm 10.6$ months in the endoscopy group. The discrepancy with regard to previous studies is probably due to various factors. On the one hand, patient selection type for each treatment group must be taken into account. As table I shows, the patients in group 1 have a greater frequency of the clinical and laboratory risk factors put forward by Pitt et al (23), which define patients with a greater probability of post-procedure complications of the biliary duct than patients in the surgery group. Thus, age, number of leukocytes, hemoglobinemia, serum levels of creatinine and alkaline phosphotase are greater in the first group than in the second group.

On the other hand, another factor to take into account is the high proportion of patients who underwent more aggressive surgery with ample palliative resections. In our series, of 37 patients operated on, palliative resection was performed on 20 , and 17 underwent biliodigestive bypass exclusively. Despite a lack of randomized trials showing better results for resection when compared with bypass surgery, results obtained for resection from retrospective studies are better than or at least equal to those published for bypass surgery $(24,25)$. Two recent works compare the prognostic parameters of the two surgical procedures $(26,27)$, concluding that perioperative morbidity and mortality after palliative resection is acceptable and similar to bypass surgery, with complication figures 
for resection between $42-44 \%$, and $32-33 \%$ after bypass surgery, with a mortality rate of 2 and $1 \%$, respectively. Survival in both studies was greater after palliative resection than after bypass surgery. In the series by Lillamoe et al. (26), survival after 2 years was 16 against $8 \%$, and Reider et al. (27) found 24 against $2 \%$, respectively. These facts have led to a change in treatment strategies by specialist centers, where surgeons experienced in this field prefer to perform tumor resections. In our series (Table IV), the mean survival obtained after palliative resection is higher than that of bypass surgery.

As stated previously, the purpose of applying palliative treatment to a patient with malignant obstructive jaundice is not only to increase long-term survival, but also to maintain good quality of life during the period of time between the diagnosis of the disease and the patient's death. Symptoms that have proved to be related to good quality of life include mainly pruritus, anorexia, dyspepsia, diarrhea and malaise, as well as jaundice. Two clinical studies $(14,15)$ which used protocolized questionnaires and were approved by the European Organization for Research and Treatment of Cancer, show a significant improvement of these symptoms in patients with malignant biliary obstruction undergoing endoscopic biliary drainage by means of stent insertion. Only one randomized study (19) compares the two treatment procedures referring to quality of life. The period of good quality of life is defined as the mean survival percentage of time during which the patient can carry out a normal physical activity. The mean survival percentage of patients with a normal activity without the need for help was $57 \%$ for those treated with endoscopic biliary drainage, and 51\% for those undergoing surgical treatment, with no significant differences. In our series, good quality of life is defined as absence of jaundice, pruritus and cholangitis; disease-free survival after the operation was analyzed and the comfort index was calculated, both as measures which express, simply and objectively, the quality of life of these patients. Disease-free survival was 10.5 months in the surgery group, and 4 months in the endoscopy group, though the comfort index was similar in both groups, at 34 and $42.5 \%$, respectively. With these results it may be stated that the quality of life provided by both palliative treatment procedures is similar in patients with malignant obstruction of the biliary duct.

It may be concluded that endoscopic biliary drainage by means of stent insertion and palliative surgery are effective treatments for malignant obstructive jaundice, with the same perioperative mortality rate and subsequent retreatment requirements. However, in our group of patients, surgery offers increased survival and diseasefree survival, despite not influencing the comfort index. This fact implies that the type of procedure applied offers proportionally the same quality of life in this disease. In any case, quality of life is a prognostic variable that has not been evaluated in controlled and randomized studies, and it would be necessary to define it accurately and analyze which is the best treatment option in order to offer the patient a healthier and more comfortable survival period. Regarding surgical treatment, the results from our series and from other trials do not currently allow recommending routine palliative resection, nor do they justify the operation as a reductive process of tumor mass. However, further studies are required including greater numbers of patients in order to obtain more conclusive results.

\section{REFERENCES}

1. Naranjo A, Hervás A, Miño G. Drenaje biliar endoscópico de las ictericias obstructivas malignas. En: Naranjo A, Hervás A, Miño G, eds. Drenaje biliar endoscópico. Indicaciones y resultados. Madrid, 1998. p. 41-73.

2. Cello JP. Carcinoma of pancreas. En: Sleisinger MH. Fordtran JS, ed. Gastrointestinal disease. Pathophysiology, diagnosis, management. Philadelphia: Saunders, 1998. p. 1682-94.

3. Kozarek RA. Endoscopy in the management of pancreatic cancer. Sociedad Española de Patología Digestiva y American Society for Gastrointestinal Endoscopy. Curso de Postgraduados en Avances y Actualización de Endoscopia Digestiva. Madrid, 1997. p. 19-29.

4. Gores GJ. Clinicopathologic features of neoplastic cholangiopaties. American Association for the study of liver diseases. Postgraduate course. Diseases of the bile ducts: pathogenesis, pathology and practice. Chicago, 1996. p. 197-204.

5. Malfertheiner P, Ebert M, Domínguez-Muñoz J. Progress and update in pancreatology, 1995. European Association for Gastroenterology Postgraduate course. Berlin, 1995.

6. Waranapa P, Williamson RCN. Surgical palliation for pancreatic cancer: developments during the past two decades. Br J Surg 1992; 79: 820.

7. Speer A, Cotton PB, Russell RCG. Randomized trial of endoscopic versus perccutaneous stent insertion in malignant obstructive jaundice. Lancet 1987; 2: 57-62.

8. Sonnenfeld T, Gabrielsson N, Granqvist S, Perbeck L. Nonresectable malignant bile Duct obstruction. Surgical bypass or endoprosthesis? Acta Chir Scand 1986; 152: 297-300.

9. Pasanen P, Partanen K, Pikkarainen P, Alhava E, Pirinen A, Janatuinen E. Complications of endoscopic retrograde cholangiopancreatography in jaundiced and cholestasic patients. Ann Chir Gynaecol 1992; 81: 28-31.

10. Costamagna G, Gabriella A, Mutignani M, Perri V, Buononato M, Crucitti F. Endoscopic diagnosis and treatment of malignant biliary strictures: review of 505 patients. Acta Gastroenterol Belg 1993; 56: 201-6.

11. Karsten TM, Coene PLO, van Gulik TM, Bosma A, van Marle J, James J. Morphologic changes of extrahepatic bile ducts during obstrucction and subsequent decompression by endoprosthesis. Surgery 1992; 111: 562-8.

12. Armitage E, Rhodes M, Puntis M, Lawrie B. Endoscopic or surgical management for jaundice caused by carcinoma of the pancres. Gastroenterology 1994; 106: A284.

13. Wilson C, van Wyck MEC, Funnell I, Krige JEJ, Bornman PC, Terblanche J. Pancreatic carcinoma: an audit of treatment, survival and quality of life. Inaugural World Congress of Internantional Hepato-Pancreato-Biliary Association, Boston, Ma, June 1, 1994: $138 \mathrm{~A}$.

14. Luman W, Cull A, Palmer KR. Quality of life in patient stented for malignant biliary obstructions. Eur J Gastoenterol Hepatol 1997; 9: 481-4.

15. Ballinger AB, McHugh M, Catnach SM, Alstead EM, Clark ML. Symptom relief and quality of life after stenting for malignant bile duct obstruction. Gut 1994; 35: 467-70.

16. Bismuth H, Castaing D, Traymor O. Resection or palliation: priority of surgery of disease classification system. Crit Care Med 1985; 13: $818-29$. 
17. Smith AC, Dowsett JF, Russell RC, Hatfield AR, Cotton PB. Randomised trial of endoscopic stenting versus surgical bypass in malignant low bile duct obstruction. Lancet 1994; 344: 1655-60.

18. Sherherd HA, Royle G, Ross AP, Diba A, Arthur M, Colin-Jones D. Endoscopic biliary endoprosthesis in the palliation of malignant obstruction of distal common bile Duct: a randomized trial. Br J Surg 1988; 75: 1166-8

19. Andersen JR, Sorensen SM, Kruse A, Rokkkjaer M, Matzen P. Randomised trial of endoscopic endoprosthesis versus operative bypass in malignant obstructive jaundice. Gut 1989; 30: 1132-5.

20. Raikar GV, Melin MM, Ress A, Lettieri SZ, Poterucha JJ, Nagorney DM. Cost-effective analisis of surgical palliation versus endoscopic stenting in the management of unresectable pancreatic cancer. Ann Surg Oncol 1996; 3: 470-5.

21. Leung LWC, Emergy R, Cotton PB, Russell RC, Vallon AG, Mason RR. Management of malignant obstructive jaundice at the Middlesex hospital. Br J Surg 1983; 70: 584-6.

22. Naranjo A, Puente J, Hervás A, de Dios FJ, Monrobel A, González A, et al. Drenaje endoscópico mediante prótesis de polietileno de la ictericia obstructiva maligna. Gastroenterol Hepatol 1999; 22: 391-7.

23. Pitt HA, Cameron JL, Postier RG, Gadacz TR. Factors affecting mortality in biliary tract surgery. Am J Surg 1981; 141: 66-72.

24. Gouma DJ, van Geenen R, van Gulik T, de Wit LT, Obertop H. Surgical palliative treatment in biliary-pancreatic malignancy. Ann Oncol 1999; 10: 269-72.

25. Gouma DJ, van Dijkum N, van Geenen RCI, van Gulik TM. Are there indications for palliative resection in pancreatic cancer? World J Surg 1999; 23: 954-9.

26. Lillemoe KD, Cameron JL, Yeo CJ, Sohn TA, Nakeeb A, Sauter PK, et al. Pancreaticoduodenectomy: does it have a role in the palliation of pancreatic cancer. Ann Surg 1996; 223: 718-22.

27. Reinders ME, Allema JH, van Gulik TM, Karsten TM, de Wit LT, Verbeek PCM, et al. Outcome of microscopically nonradical, subtotal pancreaicoduodenectomy (Whipple's resection) for treatment of pancreatic head tumors. World J Surg 1995; 19: 410-4.

\title{
Tumores biliopancreáticos: supervivencia y calidad de vida de los pacientes sometidos a tratamiento paliativo
}

\author{
M. V. García Sánchez, P. López Vallejos, D. Pérez de Luque, A. Naranjo Rodríguez, A. Hervás Molina, \\ A. González Galilea, B. Calero Ayala, J. Padillo Ruiz, G. Solórzano Peck y J. F. de Dios Vega \\ Servicio de Aparato Digestivo. Hospital Universitario Reina Sofía. Córdoba
}

\section{RESUMEN}

Objetivos: analizar la supervivencia y calidad de vida de los pacientes con ictericia obstructiva maligna sometidos a tratamiento paliativo, y comparar estos resultados en función de la alternativa terapéutica aplicada (prótesis biliar endoscópica frente a cirugía paliativa de resección o derivación biliodigestiva).

Pacientes y método: ochenta y siete pacientes fueron incluidos en el estudio que se distribuyeron en dos grupos: a) 50 sometidos a drenaje biliar endoscópico con colocación de endoprótesis; y b) 37 intervenidos quirúrgicamente. Se analizó la supervivencia y calidad de vida del enfermo, entendiendo como buena calidad de vida la ausencia de ictericia, prurito y colangitis tras el primer abordaje terapéutico. Se calculó el índice de confort según el cual el periodo de buena calidad de vida se expresa como porcentaje de supervivencia.

Resultados: el tiempo medio de supervivencia fue de 9,6 meses en los enfermos drenados por vía endoscópica frente a 17 meses en los intervenidos quirúrgicamente. El tiempo asintomático de enfermedad fue de 4 meses frente a 10,5 meses, respectivamente. No hubo grandes diferencias en cuanto al índice de confort entre ambos grupos terapéuticos (34 vs 42,5\%). Tampoco se encontraron diferencias llamativas entre la supervivencia y calidad de vida analizando la cirugía de resección frente a la cirugía derivativa.
Conclusiones: a pesar de que la cirugía consigue una mayor supervivencia y tiempo asintomático de enfermedad, no mejora la calidad de vida frente al drenaje biliar endoscópico. En cuanto al tipo de tratamiento quirúrgico, la cirugía de derivación y la de resección ofrecen los mismos porcentajes de supervivencia y calidad de vida, por lo que por el momento, no podemos recomendar de forma rutinaria la resección paliativa en este tipo de tumores.

Palabras clave: Ictericia obstructiva maligna. Calidad de vida. Endoprótesis biliar. Cirugía biliar. Tratamiento paliativo.

\section{INTRODUCCIÓN}

Las principales causas de obstrucción maligna de la vía biliar principal son el carcinoma ampular, el adenocarcinoma de cabeza pancreática, el colangiocarcima y el cáncer de vesícula (1).

Aunque la cirugía sigue siendo el único tratamiento que permite la curación de estas neoplasias, la mayor parte de las veces no es posible. Por una parte, la edad avanzada que generalmente tienen estos pacientes, condiciona 
la asociación habitual de enfermedades graves que contraindican la intervención quirúrgica o aumentan notablemente la morbimortalidad operatoria $(2,3)$. Por otra, el estadio evolutivo en que suelen encontrarse estos tumores en el momento del diagnóstico, hace que en muchos casos sean irresecables (2-4). Estos dos hechos justifican que más del $75 \%$ de estos enfermos sean sólo tributarios de tratamiento paliativo $(2,4,5)$.

Hoy día, las alternativas terapéuticas paliativas de las que disponemos para aliviar la obstrucción de la vía biliar son el drenaje biliar endoscópico o percutáneo mediante colocación de endoprótesis y la cirugía con derivación biliodigestiva o resección no curativa. Hasta mediados de 1980, estos pacientes eran sometidos a una intervención quirúrgica para intentar una resección o, en la mayoría de los casos, realizar un drenaje biliar paliativo (6). A partir de la década de los ochenta, comenzó a utilizarse el drenaje percutáneo, pero la morbilidad asociada a dicha técnica, motivó que fuera relegada y por tanto preferida la vía endoscópica (7). A pesar de los múltiples estudios que han sugerido que el drenaje biliar endoscópico es una técnica segura y eficaz con una baja tasa de complicaciones perioperatorias y mortalidad, su superioridad frente a la cirugía de derivación no ha sido aún demostrada $(8,13)$. Por otro lado, el propósito de estos tratamientos no es sólo conseguir la paliación de la ictericia e incrementar la supervivencia del enfermo, sino aumentar el tiempo asintomático de la enfermedad entre su diagnóstico y la muerte del paciente. En este sentido, hay estudios que demuestran la mejoría de la calidad de vida de los enfermos con obstrucción maligna de la vía biliar tras la inserción de una endoprótesis por vía endoscópica $(14,15)$, pero muy pocos han contrastado los resultados entre esta alternativa terapéutica y la cirugía paliativa. Por todo ello, el objetivo principal de nuestro estudio es analizar la supervivencia y calidad de vida aportadas por el drenaje biliar endoscópico y por el tratamiento quirúrgico paliativo de los pacientes con ictericia obstructiva maligna de la vía biliar principal.

\section{PACIENTES Y MÉTODO}

Se han estudiado de manera retrospectiva 87 pacientes con obstrucción maligna de la vía biliar tributarios de tratamiento paliativo, ingresados entre enero de 1998 y diciembre de 2001. Sólo se incluyeron enfermos con diagnóstico histológico de malignidad o con una colangiografía y al menos otra técnica de imagen (ecografía, TAC o colangioRM) compatibles y que siguieron una evolución clínica de enfermedad maligna. Se excluyeron aquellos pacientes con historia previa de otra enfermedad neoplásica durante los 5 años anteriores, los que tenían difícil acceso endoscópico a la papila (p. ej. gastrectomía con Billroth II) y los sometidos a drenaje biliar percutáneo mediante colangiografía transhepática.
Se clasificaron a los pacientes en dos grupos en función del tratamiento paliativo aplicado. El grupo 1 estaba constituido por 50 enfermos que se sometieron a drenaje biliar endoscópico con colocación de endoprótesis y el grupo 2, por 37 enfermos intervenidos quirúrgicamente.

El procedimiento se consideró satisfactorio cuando, además de una correcta colocación de la prótesis o una adecuada anastomosis quirúrgica biliodigestiva, la evolución clínica del paciente fue favorable (mejoría del prurito y descenso de la colemia al menos un $30 \%$, cinco días después del drenaje) y en controles ecográficos se evidenciaba una disminución del calibre de la vía biliar. En ausencia de estos criterios el drenaje se consideró ineficaz.

Todos los pacientes se siguieron hasta su muerte, revisándose a los 30 días después del drenaje y luego trimestralmente, incluyendo en cada visita una analítica y una ecografía abdominal.

Se recogieron las siguientes variables clínicas y analíticas: edad, sexo, presencia de enfermedades médicas asociadas, tipo de tumor, cifra de leucocitos, hemoglobinemia, creatinina sérica, colemia y fosfatasa alcalina sérica.

Las complicaciones y la mortalidad en los 30 primeros días tras el tratamiento se definieron como la morbilidad y mortalidad precoz respectivamente. Se registró la estancia hospitalaria tras la intervención quirúrgica o colocación de la endoprótesis inicial, el número y causas de reingresos, asî como la necesidad de nuevas intervenciones sobre la vía biliar o digestiva. Se analizó la supervivencia y calidad de vida del enfermo, entendiendo como buena calidad de vida la ausencia de ictericia, prurito y colangitis tras el primer abordaje terapéutico. Se calculó el índice de confort según el cual el periodo de buena calidad de vida se expresa como porcentaje de supervivencia (16).

$$
\text { Índice de confort: } \frac{\text { Buena calidad de vida (meses) }}{\text { Supervivencia (meses) }} \times 100
$$

El drenaje biliar endoscópico se realizó bajo sedación por vía intravenosa con midazolán y se emplearon duodenoscopios Olympus TJF-10 y TJF-130 con canal terapéutico de 4,2 mm. Se colocaron, previa dilatación, prótesis de polietileno tipo Ámsterdam (Izasa-GIP Medizintechnik) o Pig-Tail (Baston Scientific/ Microvasive), de un calibre de $10 \mathrm{~F}$ en la práctica totalidad de los casos, y longitudes variables según la situación de la estenosis. La intervención quirúrgica paliativa se decidió por el equipo de cirujanos responsables del paciente. En 20 enfermos se realizó una resección paliativa y 17 , fueron sometidos a derivación biliodigestiva mediante coledocoduodenostomía, colecistoyeyunostomía o gastroenterostomía. Ningún paciente recibió radioquimioterapia complementaria.

Se realizó un estudio descriptivo de las variables recogidas en cada grupo terapéutico, y se empleó la curva de Kaplan-Meier para el análisis de la supervivencia y el tiempo asintomático de enfermedad. 


\section{RESULTADOS}

La edad media fue de 70,6 años (rango 37-92), 42 eran hombres y 51 tenían enfermedades crónicas graves asociadas. En la tabla I se detallan las características generales de cada grupo.

El nivel de la obstrucción se localizó en la vía biliar proximal en 23 pacientes (26\%), en la vía biliar distal en $41(48 \%)$ y en $23(26 \%)$ casos se debió a un ampuloma. En tabla II se especifica la distribución de la serie según la localización de la neoplasia.

Los resultados de las variables pronósticas en función del tipo de tratamiento paliativo aplicado (endoscópico, quirúrgico), y según la técnica quirúrgica empleada (resección paliativa, cirugía de derivación) se muestran en las tablas III y IV respectivamente.

\section{Tabla I. Características generales}

\begin{tabular}{|c|c|c|}
\hline & Grupo 1 & Grupo 2 \\
\hline Número $(n)$ & 50 & 37 \\
\hline Edad (media $\pm \mathrm{DE})$ & $70 \pm 10$ & $64 \pm 11$ \\
\hline \multicolumn{3}{|l|}{ Sexo: $n(\%)$} \\
\hline Hombre & $23(46)$ & $19(51)$ \\
\hline Mujer & $27(54)$ & $18(49)$ \\
\hline Enfermedades asociadas, n (\%) & $30(60)$ & $21(57)$ \\
\hline \multicolumn{3}{|l|}{ Tipo de tumor: $\mathrm{n}(\%)$} \\
\hline Proximal & $15(30)$ & $8(22)$ \\
\hline Distal & $19(38)$ & $22(59)$ \\
\hline Ampuloma & $16(32)$ & $7(19)$ \\
\hline $\begin{array}{l}\text { Leucocitos, } \mathrm{mm}^{3} / \mathrm{dl} \\
\quad \text { (media } \pm \mathrm{DE})\end{array}$ & $8009 \pm 3251$ & $7543 \pm 2250$ \\
\hline $\begin{array}{l}\text { Hemoglobina, } g / d l \\
\quad(\text { media } \pm \mathrm{DE})\end{array}$ & $12 \pm 1,4$ & $13 \pm 1,35$ \\
\hline $\begin{array}{r}\text { Creatinina, g/dl } \\
\quad(\text { media } \pm \text { DE })\end{array}$ & $1,1 \pm 1,1$ & $1 \pm 0,2$ \\
\hline $\begin{array}{l}\text { Bilirrubina total, mg/dl } \\
\quad(\text { media } \pm \text { DE) } \\
\text { Fosfatasa alcalina, UI/L }\end{array}$ & $16 \pm 8$ & $12 \pm 9$ \\
\hline$($ media $\pm D E)$ & $1038 \pm 1073$ & $972 \pm 629$ \\
\hline
\end{tabular}

n: tamaño de la muestra. DE: desviación estándar. p: probabilidad

Tabla II. Localización de la neoplasia

\begin{tabular}{lcc}
\hline Tipo de tumor & $n$ & $\%$ \\
\hline Ampuloma & 23 & 26 \\
Cáncer de páncreas & 35 & 40 \\
Cáncer de vesícula & 11 & 13 \\
Colangiocarcinoma & 18 & 21 \\
$\quad$ Tipo I de Bismuth & 3 & 17 \\
Tipo II-III de Bismuth & 4 & 22 \\
Medio / Distal & 11 & 61 \\
\hline
\end{tabular}

n: tamaño de la muestra. p: probabilidad

En la tabla V presentamos el tiempo asintomático de enfermedad, supervivencia e índice de confort según la localización del tumor y el tipo de tratamiento paliativo
Tabla III. Variables pronósticas

\begin{tabular}{|c|c|c|}
\hline & Grupo 1 & Grupo 2 \\
\hline Eficacia de la técnica: n (\%) & $47(94)$ & $35(95)$ \\
\hline Morbilidad precoz: n (\%) & $4(8)$ & $12(32)$ \\
\hline Mortalidad precoz: n (\%) & $6(12)$ & $4(11)$ \\
\hline \multicolumn{3}{|l|}{ Estancia hospitalaria, días: } \\
\hline media $\pm D E$ & $12,5 \pm 7,5$ & $35 \pm 10$ \\
\hline Reingresos: $n(\%)$ & $14(28)$ & $5(8)$ \\
\hline Reintervenciones: n (\%) & $11(22)$ & $5(13)$ \\
\hline CPRE & 9 & 0 \\
\hline Cirugía & 2 & 5 \\
\hline $\begin{array}{l}\text { Tiempo asintomático de } \\
\text { enfermedad, meses: } \\
\text { media } \pm \mathrm{DE}\end{array}$ & $4 \pm 5,5$ & $10,5 \pm 14$ \\
\hline $\begin{array}{l}\text { Supervivencia, meses: } \\
\text { media } \pm \mathrm{DE} \\
\text { Índice de confort, \%: }\end{array}$ & $9,6 \pm 10,6$ & $17 \pm 19$ \\
\hline media $\pm D E$ & $34 \pm 23$ & $42,5 \pm 29$ \\
\hline
\end{tabular}

Tabla IV. Medidas pronósticas según el tipo de tratamiento quirúrgico aplicado

\begin{tabular}{|c|c|c|}
\hline & Resección & Derivación \\
\hline Número (n) & 20 & 17 \\
\hline Morbilidad precoz: $n(\%)$ & $6(30)$ & $6(35)$ \\
\hline Mortalidad precoz: n (\%) & $1(5)$ & $3(17)$ \\
\hline Estancia hospitalaria, días: media $\pm \mathrm{DE}$ & $35,7 \pm 10,6$ & $34 \pm 9,3$ \\
\hline Reingresos: n (\%) & $2(10)$ & $1(6)$ \\
\hline Reintervenciones: $\mathrm{n}(\%)$ & $4(20)$ & $1(6)$ \\
\hline \multicolumn{3}{|l|}{ Tiempo asintomático de } \\
\hline enfermedad, meses: media \pm DE & $11 \pm 11$ & $10 \pm 17$ \\
\hline Supervivencia, meses: media \pm DE & $18 \pm 16$ & $16 \pm 22,6$ \\
\hline Índice de confort, \%: media $\pm \mathrm{DE}$ & $54 \pm 26$ & $29 \pm 27$ \\
\hline
\end{tabular}

n: tamaño de la muestra. p: probablidad. DE: desviación estándar

Tabla V. Supervivencia y calidad de vida según la localización del tumor y el tratamiento paliativo aplicado

\begin{tabular}{cccc}
\hline & $T A E(m)$ & $S(m)$ & $I C(\%)$ \\
\hline Adenocarcinoma de páncreas & & & \\
$\quad$ Grupo 1: 14 & $3 \pm 6$ & $7 \pm 10$ & $32 \pm 25$ \\
$\quad$ Grupo 2: 21 & $9 \pm 9$ & $15 \pm 15$ & $42 \pm 28$ \\
Carcinoma ampular & $6 \pm 5$ & $16 \pm 12$ & $37 \pm 23$ \\
$\quad$ Grupo 1: 16 & $22 \pm 22$ & $35 \pm 27$ & $45 \pm 35$ \\
$\quad$ Grupo 2: 7 & $2 \pm 2$ & $6 \pm 6$ & $30 \pm 15$ \\
Colangiocarcinoma & $18 \pm 25$ & $19 \pm 24$ & $75 \pm 35$ \\
$\quad$ Grupo 1: 16 & $6 \pm 12$ & $7 \pm 11$ & $41 \pm 44$ \\
$\quad$ Grupo 2: 2 & $2 \pm 2$ & $5 \pm 5$ & $33 \pm 24$ \\
Neoplasia vesicular & Grupo 1: 4 & & \\
Grupo 2: 7 & & & \\
\hline
\end{tabular}

TAE (m): tiempo asintomático de enfermedad (meses). $\mathrm{S}(\mathrm{m})$ : supervivencia (meses). IC (\%): índice de confort (\%).

empleado. Comprobamos que el resultado de estas variables fue mejor tras el tratamiento quirúrgico aunque sin grandes diferencias. El ampuloma fue el tumor con mejor pronóstico en contraposición con el carcinoma de vesícula que fue el de peor pronóstico. 
En 47 pacientes (94\%) se consiguió un drenaje endoscópico satisfactorio y en 35 (95\%) la anastomosis biliodigestiva fue adecuada. La morbilidad precoz fue de 16 pacientes, con mayor proporción en el grupo quirúrgico (32\%) frente al grupo endoscópico (8\%). Las complicaciones más frecuentes fueron las derivadas de una dehiscencia de la anastomosis (6), seguida de complicaciones respiratorias (3), insuficiencia renal (3), infecciones (2), descompensación cardiaca (1) y hemorragia digestiva alta (1). La mortalidad precoz fue similar en ambos grupos, en 6 casos por lo avanzado de la enfermedad neoplásica y otros 4 , tras complicaciones del drenaje biliar (2 tras el drenaje endoscópico y otros 2 tras el drenaje quirúrgico).

Si bien el número de reingresos fue superior en el grupo drenado endoscópicamente frente al quirúrgico (14/50, 5/37 respectivamente), no se apreció una diferencia importante en la necesidad de reintervenciones endoscópicas o quirúrgicas (11/50 frente 5/37). Once pacientes del grupo drenado por vía endoscópica requirieron reintervención posterior, 10 por obstrucción de la prótesis realizándose un recambio de la misma (en 5 enfermos se sustituyó una vez, en 4, dos veces y en uno, cuatro veces), y uno para cirugía derivativa por obstrucción duodenal secundaria a crecimiento tumoral. La causa de reintervención quirúrgica en los 5 enfermos del grupo 2 fue dehiscencia de sutura de la anastomosis. La estancia media hospitalaria tras la primera actuación fue mayor en el grupo quirúrgico frente al grupo endoscópico.

Los enfermos intervenidos quirúrgicamente obtuvieron una supervivencia y un tiempo asintomático de enfermedad superior frente a los drenados por vía endoscópica (Figs. 1 y 2). Sin embargo, no hubo diferencias considerables en el índice de confort entre ambos procedimientos terapéuticos.

La supervivencia, tiempo asintomático de enfermedad e índice de confort fueron mayores en el grupo sometido a cirugía de resección frente al de derivación (Tabla IV), sin diferencias destacables en cuanto al resto de las variables pronósticas.

\section{DISCUSIÓN}

El drenaje biliar endoscópico y la cirugía paliativa son opciones terapéuticas aceptadas en la ictericia obstructiva maligna, con una tasa de éxitos superior al $90 \%$ y sin diferencias significativas entre ambas $(17,18)$. La eficacia de nuestra serie fue del $94 \%$ en el grupo sometido a drenaje biliar endoscópico y del $95 \%$ en el grupo intervenido quirúrgicamente.

La mortalidad precoz de nuestros pacientes es similar a la de las series publicadas hasta el momento, que la sitúan en un 8-24\% (17-21). Sin embargo, ya se había sugerido en estudios previos que la aparición de complicaciones perioperatorias eran más frecuentes en el grupo quirúrgico frente al grupo drenado por vía en- doscópica (17-19). El estudio randomizado de Smith y cols. (17), en el cual se considera y define la morbilidad precoz de forma muy similar a la de nuestro estudio, obtiene un $29 \%$ de complicaciones con la cirugía frente a un $11 \%$ tras la colocación de una endoprótesis por vía endoscópica. En nuestra serie, el porcentaje de morbilidad tras la cirugía fue del 32 frente al $8 \%$ tras el drenaje biliar endoscópico.

La paliación terapéutica por vía endoscópica también ha demostrado en tres estudios $(18,20,21)$, uno de ellos randomizado (18), disminuir el número de días de hospitalización frente a la cirugía. En nuestra serie, los enfermos sometidos a drenaje biliar endoscópico permanecieron ingresados durante 12,5 días frente a 35 días, de los enfermos sometidos a cirugía paliativa.

Uno de los mayores inconvenientes de la terapeútica endoscópica frente a la cirugía es el mayor porcentaje de reingresos tras la primera intervención. Estos resultados han sido publicados en varios estudios clínicos, aunque los tests de significación estadística no han sido expuestos $(18,20,21)$. En nuestra serie, el $28 \%$ de los pacientes drenados por vía endoscópica reingresaron frente al $8 \%$ del grupo quirúrgico. La reaparición de la ictericia, en algunos casos con colangitis e incluso sepsis, fue la causa más frecuente de reingreso, y la necesidad de recambio de la prótesis el motivo fundamental de reintervención sobre la vía biliar. Se ha comunicado que el 37\% de las endoprótesis plásticas se ocluyen a pesar de las medidas terapéuticas empleadas (sales biliares), como consecuencia del depósito en su superficie interna de material amorfo, y en estos casos es necesario el recambio de la misma $(17,22)$. En nuestra serie, el porcentaje ha sido algo mayor, del $41 \%$, y la media de prótesis colocadas a un paciente fue de 1,7 , cifra similar a la publicada por Raiker y cols. (20).

En cuanto al análisis de supervivencia en los enfermos con ictericia obstructiva maligna en función del tratamiento paliativo aplicado, no se encuentran diferencias significativas en los estudios publicados hasta el momento $(17,19-21)$. Sin embargo, en nuestra serie, la supervivencia de los enfermos del grupo quirúrgico fue de $17 \pm$ 19 meses frente al grupo endoscópico, que fue de 9,6 \pm 10,6 meses. Esta discrepancia con respecto a estudios previos probablemente sea consecuencia de varios factores. Por un lado hay que tener en cuenta el tipo de selección de los pacientes asignados a cada brazo terapéutico. Como podemos apreciar en la tabla I, los pacientes del grupo 1 tienen con más frecuencia los factores de riesgo, clínicos y analíticos propuestos por Pitt y cols. (23), los cuales definen a los enfermos con mayor probabilidad de complicaciones postintervención de la vía biliar, frente al grupo intervenido quirúrgicamente. Así, la edad, la cifra de leucocitos, hemoglobinemia, creatinina sérica, bilirrubinemia y fosfatasa alcalina son mayores en el primer grupo frente al segundo.

Por otro lado, otro factor a tener en cuenta es la elevada proporción de pacientes intervenidos quirúrgicamente so- 
metidos a una cirugía más agresiva con resecciones paliativas amplias. En nuestra serie, de los 37 pacientes operados, en 20 se realizó una resección paliativa y en 17 una derivación biliodigestiva exclusivamente. A pesar de que no existen trabajos randomizados que demuestren la superioridad de la resección frente a la cirugía derivativa, los resultados obtenidos de estudios retrospectivos son mejores para la resección o por lo menos iguales a los publicados para la derivación quirúrgica $(24,25)$. En dos trabajos recientes $(26,27)$ se comparan los parámetros pronósticos de ambos procedimientos quirúrgicos, concluyendo que la morbilidad y mortalidad perioperatoria después de la resección paliativa era aceptable y similar a la derivación quirúrgica, alcanzando cifras de complicaciones para la resección entre el $42-44 \%$ frente al $32-33 \%$ tras la derivación quirúrgica, y una mortalidad del 2 frente al 1\%, respectivamente. En cuanto a la supervivencia, en ambos estudios fue mayor tras la resección paliativa que tras la cirugía derivativa. En la serie de Lillamoe y cols. (26), la supervivencia a los 2 años fue del 16 frente al $8 \%$, y en la de Reider y cols. (27) del 24 frente al $2 \%$, respectivamente. Estos hechos han determinado un cambio en las estrategias de tratamiento de centros especializados, en los cuales los cirujanos con experiencia en este campo prefieren realizar resecciones tumorales. En nuestra serie (Tabla IV), la media de supervivencia que obtenemos tras la resección paliativa es superior frente a la de la cirugía de derivación.

Como hemos anunciado anteriormente, el propósito de aplicar al enfermo con ictericia obstructiva maligna un tratamiento paliativo, no es tan sólo aumentar la supervivencia a largo plazo, sino mantenerle con buena calidad de vida durante el periodo de tiempo entre el diagnóstico de la enfermedad y su muerte. Los síntomas que han demostrado relacionarse con la buena calidad de vida son fundamentalmente el prurito, la anorexia, la dispepsia, la diarrea y el estado general, además de la ictericia. Hay dos estudios clínicos $(14,15)$, que mediante cuestionarios protocolizados y aprobados por la Organización Europea para la Investigación y Tratamiento del Cáncer, demuestran la mejoría significativa de estos síntomas en pacientes con obstrucción biliar maligna sometidos a drenaje biliar endoscópico mediante colocación de una endoprótesis. Sólo hay un estudio randomizado (19) donde se hace referencia a la calidad de vida comparando ambos procedimientos te- rapéuticos. En este, se define el periodo de buena calidad de vida como el porcentaje medio de supervivencia durante el cual el paciente podría alcanzar una actividad física normal, y obtienen que el porcentaje medio de supervivencia de los pacientes con una actividad normal sin necesidad de ayuda, fue del $57 \%$ para los tratados mediante drenaje biliar endoscópico y del 51\% para los intervenidos quirúrgicamente, sin diferencias significativas. En nuestra serie, definimos como buena calidad de vida, la ausencia de ictericia, prurito y colangitis, y analizamos el periodo de tiempo asintomático de enfermedad tras la intervención y calculamos el índice de confort, como medidas que expresan de una forma sencilla y objetiva, la calidad de vida de estos enfermos. El tiempo asintomático de enfermedad en el grupo quirúrgico fue de 10,5 meses frente a 4 meses del grupo endoscópico, sin embargo el índice de confort fue similar en ambos grupos, del 34 frente al 42,5\%, respectivamente. Con estos resultados podemos anunciar que la calidad de vida aportada por ambos procedimientos terapéuticos paliativos es similar en los pacientes con obstrucción maligna de la vía biliar.

Podemos concluir que el drenaje biliar endoscópico mediante colocación de endoprótesis y la cirugía paliativa, son tratamientos eficaces de la ictericia obstructiva maligna con la misma mortalidad perioperatoria y requerimientos de reintervenciones posteriores. Sin embargo, la intervención quirúrgica, en nuestro grupo de enfermos ofrece una mayor supervivencia y tiempo asintomático de enfermedad a pesar de no influir en el índice de confort. Este hecho implica que el tipo de procedimiento terapéutico empleado ofrece proporcionalmente la misma calidad de vida en esta enfermedad. De todas formas, la calidad de vida es una variable pronóstica que no ha sido evaluada por estudios controlados y randomizados y sería necesario definirla con exactitud y analizar cuál es la mejor opción terapéutica con el fin de ofrecerle al enfermo un periodo de supervivencia más saludable y confortable. En cuanto al tipo de tratamiento quirúrgico, los resultados de nuestra serie y la de otros estudios, no permiten por el momento la indicación de forma rutinaria de la resección paliativa, ni justifican dicha operación como proceso reductor de masa tumoral, en este sentido hacen falta estudios con mayor número de pacientes con el fin de extraer resultados más concluyentes. 
